İnceleme Makalesi - Review Article

\title{
Destekten Yoksun Kalma Tazminatı Kapsamında Çocuğun Durumu $^{1}$
}

\section{The Status of the Child in Scope of Compensation Loss of Support}

\author{
Özgür Hakan ÇAVUŞ* \\ (iD) 0000-0002-0124-8812
}

\author{
Sosyal Güvenlik Dergisi / Journal of Social Security \\ Cilt: 10 Sayı: 1 Y1l: 2020 /Volume: 10 Issue: 1 Year: 2020 \\ Sayfa Aralığı: 41-58 / Pages: 41-58 \\ DOI: 10.32331/ sgd.752109
}

\section{ÖZ}

Destekten yoksun kalma tazminatı, ölenin destek verdiği kişilerin hayatlarının ölüm nedeniyle kötüleşmemesi için kabul edilmiş bir maddi tazminat türüdür. Ölen sigortalı çocuğun anne ve babasına bağlanacak ölüm geliri ile destekten yoksun kalma tazminatı hem mevzuat hem de kapsam olarak birbirinden farklı kavramlar olmasına rağmen ölüm geliri bağlanan anne-babanın destekten yoksun kalma tazminatına hak kazanamayacakları yönünde Yargıtay karar vermekteydi. Yargıtay İçtihatı Birleştirme Büyük Genel Kurulunun 2018 yılında verdiği karar ile annebabanın, çocuğunun haksız fiil ve/veya akde aykırılık sonucu ölmesi nedeniyle açtığı destekten yoksun kalma tazminatı davalarında, desteklik ilişkisinin varlığının ispat1 için Sosyal Güvenlik Kurumundan gelir bağlanması şartının aranmayacağı, destekten yoksun kalma tazminatı davalarında çocukların anne-babaya destek olduklarının, karine olarak kabulünün gerektiğine karar vermiştir. Çalışmamızda destekten yoksun kalma tazminatı konusu, değişen içtihat kapsamında değerlendirilmiştir.

Anahtar Sözcükler: Destekten yoksun kalma tazminatı, iş kazası, meslek hastalığı, Borçlar Kanunu, Sosyal Sigortalar ve Genel Sağlık Sigortası Kanunu

\section{ABSTRACT}

Compensation for loss of support is the damages incurred by those supported in consequence of the cease of the support that was used to be provided by the deceased while living. The death benefit to be granted to the parents of dead child and the compensation for loss of damage are concepts different from each other in terms of both the legislation applicable to those concepts and their scope, however the Appeal Court used to pass decisions ruling that parents to whom death benefit is granted cannot be entitled to compensation for loss of support. As per the decision passed by the Appeal Court's Grand General Assembly for Unification of Decisions in 2018, it has been ruled that, in the actions for compensation for loss of support initiated by the parents due to death of their child in consequence of tort and/or breach of contract, it will no more be sought as a requirement that a benefit has been put on the parents by the Social Security Institution in order to prove the relationship of support and, in actions for compensation for loss of support, it should be accepted as a presumption that the child used to support the parents. In our study, actions for compensation for loss of damage has been analysed within the scope of the changing case law.

Keywords: Compensation loss of support, workplace accident, occupational disease, Turkish Code of Obligations, Social Insurance and General Health Insurance Law

Önerilen atıf şekli: Çavuş, Ö. H. (2020). Destekten Yoksun Kalma Tazminatı Kapsamında Çocuğun Durumu. Sosyal Güvenlik Dergisi (Journal of Social Security). 10(1). 41-58.

Geliş Tarihi/Received: 27/01/2020 • Güncelleme Tarihi/Revised: 14/05/2020 • Kabul Tarihi/Accepted: 16/06/2020

\footnotetext{
* Doç. Dr., Manisa Celal Bayar Üniversitesi, İktisadi ve İdari Bilimler Fakültesi, Çalışma Ekonomisi ve Endüstri İlişkileri Bölümü, ohcavus@gmail.com

1 Bu çalışma 01-03 Kasım 2019 tarihleri arasında Aydın'da III. Uluslararası Eurefe Kongresinde sunulan bildirinin önemli ölçüde gözden geçirilmiş ve genişletilmiş şeklidir.
} 


\section{GİRIŞ}

Destekten yoksunluk kavramı, "ölenin parasal, bedensel ve düşünsel etkinliğiyle sağladı̆̆ yardımlardan, hizmetlerinden, bakım ve gözetiminden, korumasından, bilgi ve deneyimleriyle yol göstermesinden yoksun kalınması" şeklinde tanımlanabilmektedir (Çelik, 2016: 16). Sorumluluk hukukunda, zararın tazminini talep hakkı doğrudan zarar görene tanınmıştır. Sorumluluk hukukunun temel ilkelerinden birisi olan "tazminat talebinde bulunacakların doğrudan zarara uğrayanlarla sınırlı olması" ilkesinin bir istisnası olarak kanun koyucu tarafından ölenin desteğinden yoksun kalanların uğradıkları zararların tazminini mümkün hale getiren düzenlemeler yapılmıştır (Çakırca, 2012: 165-166). Destekten yoksun kalma tazminatı, destek niteliğini taşıyan kişinin ölmesi nedeniyle desteğin yardımından yararlanan kişilerin talep edebileceği özel bir tazminat türüdür (Oğuzman ve Öz, 2018: 124). Ancak destekten yoksun kalma tazminatı talep edebilmek için ölen kişiden yaşarken destek alındığının ispatlanması gerekmektedir (Karahasan, 2003: 409). Destek niteliğini taşıyan kişinin ölümü nedeniyle yaşarken destek verdiği herhangi bir kimse/kimseler tazminat talep edebilirler. Destekten yoksun kalma tazminatı, zarar görenin şahsında asli ve bağımsız olarak doğan bir talep hakkı olduğu için mirasçı olsun veya olmasın ölen kişi arasında destek ilişkisi olan herkes bu tazminatı talep etme hakkına sahiptir (Antalya, 2018: 474). Ölenden destek alan kişi, ölenin; annesi, babası, kardeşi, nişanlısı, amcası, dayısı gibi herhangi bir yakını da olabilir. Genel olarak anne-babanın çocuklarına, çocukların anne-babalarına, eşlerin birbirlerine yaşarken destekte bulundukları kabul edilir (Koçoğlu, 2017: 203).

Destekten yoksun kalma tazminatı, Türk Borçlar Kanunu'nun (TBK) 53. ve 55. maddelerinde düzenlenmiştir. Bu tazminata konu zarar, doğrudan zarar olmayıp yansıma yoluyla uğranılan bir zarar olarak nitelendirildiği için farklı özellik taşımaktadır (Tekinay vd.1993: 849-850). Haksız fiil ya da sözleşmeye aykırılık sonucu ölen kişinin yaşarken destek olduğu kişi/kişiler desteğin ölümü nedeniyle söz konusu destekten mahrum kaldıkları için bir zarara uğramaktadırlar. Bu zarar öğretide "yansıma zarar" olarak nitelendirilmektedir (Oğuzman ve Öz, 2018: 44). Destekten yoksun kalma tazminatı, “destek" niteliğindeki kişinin hukuka aykırı bir fiil sonucu ölümü nedeniyle destek olunan kişilere tanınmış özel bir tazminat türüdür. Bu durum hukuka aykırı fiil sonucunda, yansıma zarara uğrayan kişilerin tazminat talebinde bulunamayacağına yönelik genel kurala kanun koyucu tarafından bir istisnadır (Antalya, 2018: 469; Gökyayla, 2004: 50; Oğuzman ve Öz, 2018: 43). Burada ölüm olayı doğrudan destek görenlerin şahsında meydana gelmediği için kanunda özel bir düzenleme olmadan yansıma zarar talep edilemez (Seven, 2017: 55).

Yansıma yoluyla ortaya çıkan zarara neden olan bu desteklik ilişkisi içinde zarar verici olay nedeniyle ölen kişinin desteğinden yoksun kalan veya kalacak olan kişilerin zarar verene karşı destekten yoksun kalma tazminatı talep hakkı doğmaktadır (Koçoğlu, 2017: 202). Destekten yoksun kalma tazminatı, ölen kişinin şahsından da bağımsızdır (Kocabaş, 2014: 3-4).

Çalışmamızın amacı kapsamında öncelikle sorumluluk hukuku ile ilgili kavramlara yer verilmiş daha sonra işverenin hukuki sorumluluğu ile ilgili değerlendirmeler yapılmıştır. Çalışmamızın konusunu oluşturan çocuğun anne-babasına destekliği ile ilgili Yargıtay İçtihadı Birleştirme Kararı Büyük Genel Kurul Kararı ele alınmıştır. 


\section{I- SORUMLULUK KAVRAMI}

Sorumluluk kavramı geniş anlamda "edimini ifa etmeyen borçlunun hukuka aykırı fiili ya da borç ilişkisine aykırı davranışları nedeni ile ortaya çıkan zararı tazmin etme yükümlülüğü” olarak nitelendirilmektedir. Zarar görenin ortaya çıkan zararı başka bir kişiye tazmin ettirmesine imkânı veren sebeplere "sorumluluk sebepleri" denilmektedir (Güneren, 2018: 610). Borçlar hukuku kapsamında zararı tazmin yükümlülüğü doğuran sorumluluk sebepleri; haksız fiilden, sözleşmeden veya kanundan doğabilir. Bazı durumlarda kişinin sorumluluğu aynı anda birden fazla sorumluluk sebebine dayanabilir. Bu durum "sebeplerin yarışması" kavramıyla ifade edilmektedir. Konuyla ilgili TBK'da yapılan düzenleme ile bu sebeplerden davacı için "en iyi giderim" imkânı sağlayan sebep belli koşullar altında tercih edilebilmektedir.

TBK kapsamında sorumluluğun unsurlar1; kusur, zarar ve illiyet bağı olarak değerlendirilebilir.

\section{A- Kusur}

Kusur, "kişinin davranışının, herkesten beklenen ortalama davranış şekline aykırı durumda olmasını ve hukuken kınanabilir/ayıplanabilir nitelikte olmasını" ifade etmektedir (Oğuzman ve Öz, 2018: 54; Antalya, 2018: 21). Kusur, “kast” ve “ihmal” olarak ikiye ayrılmaktadır. Kast, "hukuka aykırı sonucun bilinerek ve istenilerek davranışın sergilenmesini ifade etmektedir. İhmal ise "hukuka aykırl sonucun istenmemesine rağmen bu sonucun gerçekleşmemesi için gereken dikkat ve özen yükümlülüğüne aykırı hareket edilmesini” ifade etmektedir (Eren, 2019: 596-598; Oğuzman ve Öz, 2018: 56-57; Güneren, 2018: 648). Ayrıca TBK'nın 49. maddesinde, “kusurlu ve hukuka aykırı bir fiille başkasına zarar veren kimsenin bu zararl gidermekle yükümlü” olduğu belirtilmiştir.

Sorumluluk hukukunun temel amacı ortaya çıkan zararı kimin hangi oranda tazmin edileceğinin tespit edilmesidir. $\mathrm{Bu}$ nedenle sorumluluğun tespiti ve tazminatın miktarını belirlemede kusur ve kusurun yoğunluğu önemli bir kıstastır (Kahveci, 2002: 131; (Koçhisarlığlu, 2004: 2-3).

Sorumluluk hukukunda bir kimsenin kusurlu davranışları nedeniyle zararlı bir sonuç ortaya çıkarken, kusursuz sorumlulukta sorumluluk; kusurlu davranışa değil kanunun öngördüğü belirli bir olguya bağlanmıştır. Bu nedenle kusursuz sorumlulukta kusur, kurucu unsur olmaktan çıkmış ve zarar ile olay arasındaki illiyet bağı daha ön plâna çıkmıştır. Kusursuz sorumlulukta sorumluluk kusura değil olayla zarar arasındaki illiyet bağına göre belirlenir (Y1lmaz, 2010: 555-557).

Kusur sorumluluğu kapsamında her koşulda fail aleyhinde bir tazminat yükümlülügünün doğabilmesi için kusurun yanında TBK'nın 49. maddesinde belirtilen hukuka aykırı fiil ve zarar unsurlarının da ortaya çıkması gerekmektedir. Ayrıca kusur sorumluluğu kapsamında bu zarar ve hukuka aykırı fiili arasında uygun illiyet bağının da bulunması şartı büyük önem taşır.

Destekten yoksun kalma tazminatı açısından da tazminat sorumlusunun kural olarak 
kusurlu olması gerekir. TBK'nın 51. maddesine göre, hâkim, tazminatın kapsamını ve ödenme biçimini, durumun gereğini ve özellikle kusurun ağırlığını göz önüne alarak belirleyecektir (Gökyayla, 2004: 85; Eren, 2019: 587).

\section{B- Zarar}

Zarar, "haksız fiil sonucunda kişi veya malvarlı̆̆ının içinde bulunduğu durum ile haksız fiil gerçekleşmemiş olsaydı kişi veya malvarlığının içinde bulunacağı durum arasındaki farkı" ifade etmektedir (Oğuzman ve Öz: 2018: 39-40). Zarar, "maddi zarar" ve "manevi zarar" olarak ikiye ayrılmaktadır. Maddi zarar, "haksız fiil sonucunda kişinin malvarlığında meydana gelen zarar" manevi zarar, "kişilik hakkının zedelenmesi nedeniyle yaşanan manevi olumsuz duyguların yol açtığı zarar" olarak nitelendirilebilir (Eren, 543, 2019: 553; Oğuzman ve Öz, 2018: 39-40, 257).

Destekten yoksun kalma tazminatına konu olan zarar, ölüm olayından hemen sonra gerçekleşmektedir (Eren, 2019: 456). Destekten yoksun kalma tazminatında zarar iki ayrı dönemdeki zararların toplamından oluşur. Bunlardan birincisi, bilinen (işlemiş) zarar dönemidir ve bu dönem kural olarak kaza ile hükme esas alınan rapor tarihi arasındaki süreyi kapsar. Ancak işçinin iş göremezlik durumunun hükümden önce ortadan kalkması halinde tazminat hesabı söz konusu iyileşmenin gerçekleştiği tarihe kadar yapılması gerekmektedir (Akın, 2001: 247). İkinci dönem olarak tabir edilen (işleyecek) bilinmeyen zarar dönemi kendi içinde aktif ve pasif dönem olarak ikiye ayrılır ve bilinen dönemin sonundan başlayan ve işçinin iş görebilirlik çağının sonunda kadar devam eden dönem "aktif bilinmeyen zarar dönemini" ifade etmektedir (Akın, 2001: 250). Ayrıca işçinin aktif olarak çalışmaya son verdiği tarih ile yaşam tablosuna göre belirlenecek muhtemel ölüm tarihi arasında geçen dönem "pasif bilinmeyen zarar dönemi" olarak adlandırılan ayrı bir dönem de yer alır (Akın, 2001: 122, 256)

TBK'nın 53. maddesinde ölüm halinde istenebilecek zararlar sayılmıştır. Bu nedenle ölüm sonucunda meydana gelen her zarar değil, kanunda öngörülen zarar kalemlerinin tazmini mümkündür. Kanunda sayılan zarar kalemlerinden maddi zarar; destekten yoksun kalma tazminatı bakımından zarar doğuran fiilin gerçekleşmesinden önce ve sonra zarar görenin malvarlığında meydana gelen eksilme olarak tanımlanabilir (Oğuzman, 2018: 318). Bu çerçevede destekten yoksun kalma tazminatının talep edildiği hallerde destek gören, ölümden önce ve sonraki zaman diliminde destek göreceği süre içerisindeki uğraması muhtemel zararı talep eder (Gökyayla, 2004: 56).

Bazı zarar verici olaylar sonucu TBK'nın 56. maddesi kapsamında, zarar verici fiil sonucunda ölüm meydana geldiğinde, ölenin yakınları manevi tazminat talep edebilirler. Ancak destekten yoksun kalma tazminatı, bir tür maddi tazminat olduğu için destekten yoksun kalanlar, manevi tazminat taleplerini destekten yoksun kalma tazminatı talebi içinde ileri süremezler (Balcı vd, 2019: 17-20).

İşverenin hukuki sorumluluğu kapsamında "zarar unsuru" önemli bir kavram olarak karşımıza çıkar. İşçi açısından iş kazaları ve meslek hastalıkları nedeniyle doğan zarar kavramı içerisine; tedavi giderleri, çalışma gücünün azalması ya da yitirilmesi, ekonomik geleceğin sarsılması, işçinin ölümü halinde de defin masrafları ile destekten yoksun kalan yakınlarının uğradıkları zararlar gibi maddi zararlar olabileceği gibi işçinin kişilik haklarının ihlal edilmesi neticesinde ortaya çıkan manevi zararlar da ortaya çıkabilmektedir (Akın, 2001: 161-162). 


\section{C- İlliyet Bağı}

Genel olarak illiyet bağ 1 , "gerçekleşen zararla sorumluluğun bağlandığı olay veya davranış arasındaki sebep sonuç ilişkisi”" olarak ifade edilmektedir (Eren, 2019: 834). Hukuki sorumluluk kapsamında, sözleşmeden doğan sorumlulukta, sözleşme dışı kusur sorumluluğunda veya kusursuz sorumlulukta (sebep sorumluluğu) illiyet bağı çok önemlidir (Kıcalığlu, 2015: 186). Bazı durumlarda illiyet bağının kesilmesi olarak ifade edilen ve tazminat yükümlülügünü ortadan kaldıran nedenler ortaya çıkmaktadır. İlliyet bağını kesen sebepler; mücbir sebep, zarar görenin kusuru ve üçüncü kişinin kusuru olmak üzere üçe ayrılmaktadır. Bu üç sebep yalnızca tehlike sorumluluğunda değil olağan sebep sorumluluğu ve kusur sorumluluğunda da kabul edilmektedir (Süzek, 2019: 427-428). Kusursuz sorumluluğun uygulandığı hallerde de tazmin yükümlülüğünün doğması için uygun illiyet bağının kesilmemiş olması zorunludur (Akın, 2001: 87).

Mücbir sebep, “failin davranışı dışında meydana gelen, öngörülmesi ve önlenmesi mümkün olmayan beklenmedik olağanüstü olayı ifade etmektedir”. Deprem gibi doğal olaylar, genel grev, sınırların kapatılması, savaş, ihtilal gibi olaylar mücbir sebeplere örnek gösterilebilir (Eren, 2019: 520-521). Zarar görenin ağır kusuru ise "illiyet bağını kesen bir durum olmasına karşın; hafif kusuru illiyet bağını etkileyen, bu nedenle tazminatta indirim sebebi olarak değerlendirilebilecek bir durumdur." (Oğuzman ve Öz, 2018: 51). Üçüncü kişinin kusurunun illiyet bağını kesebilmesi için "üçüncü kişinin kusurunun diğerlerininkine oranla daha yoğun olması” gerekmektedir (Antalya, 2018: 231).

İspatlanması sonucu, zarar ile olay arasındaki illiyet bağının kesilmesi halinde fail sorumluluktan kurtulur (Akın, 2001: 87).

\section{II- İŞVERENIN HUKUKİ SORUMLULUĞUNUN NITTELİĞİ}

\section{A- Kusursuz Sorumluluk Görüşü}

Geniş anlamda "kusursuz sorumluluk (sebep sorumluluğu)" görüşüne göre, fail kusurlu olmasa dahi fiili ile neden olduğu zararı tazmin etmekle yükümlüdür. Bu sorumluluk türünün varlığ için sorumluluğu doğuran olay ile meydana gelen zarar arasında uygun illiyet bağının olması yeterlidir (Akın, 200: 85). Bu görüşe göre, özellikle iş kazalarının meydana gelmesinde iş̧̧inin korunması ve zararın büyük kısmının işçi üzerinde kalmaması amaçlanmaktadır. Fail kendi kusursuz davranışından sorumlu olurken ayrıca kendisinin özen borcuna aykırı kusurlu ve kusursuz davranışlarından da sorumludur. Bunlarla birlikte fail, üçüncü kişilerin kusurlu ve kusursuz hallerinden de sorumlu tutulabilir (Narter, 2015: 371). Kusur kavramının aranmadığı bu sorumluluk türünde failin temyiz kudretine haiz olup olmadığına da bakılmaz. Kusur sorumluluğunun genel ilke kabul edilmesi sonucunda kusursuz sorumluluğun istisna olmasına neden olmuş ve bu durum da bu türün ancak kanun hükümleri ile düzenlenmesi ile sınırlanmasını sağlamıştır. Kusursuz sorumluluk TBK'nın 49. maddesinde genel bir ilke olarak düzenlenmiştir. Kusursuz sorumluluk türleri de olağan sebep sorumluluğu ve tehlike sorumluluğu olmak üzere ikiye ayrılmaktadır. Olağan sebep (özen) sorumluluğu, "kişi tarafindan kendisi veya hakimiyeti altında bulunan belirli bir kişi ya da bir eşya üzerinde gösterilmesi gereken özenin gösterilmemesi sonucunda meydana gelen zarardan sorumluluğu” ifade etmektedir (Eren, 2019: 452; Antalya, 2018: 247). TBK'da düzenlenen "adam çalıştıranın sorumluluğu”, "hayvan bulunduranın sorumluluğu”, "yapı malikinin sorumluluğu” olağan sebep sorumluluğu kapsamında yer almıştır. Kusursuz sorumluluğun diğer türü olarak TBK'nın 71. maddesinde düzenlenen “tehlike sorumluluğu”, en ağır kusursuz sorumluluk halidir. Söz konusu madde ile önemli ölçüde tehlike oluşturan işletmelerin faaliyetlerinden kaynaklanan zararlarda "ağır bir tehlike taşıyan işletme veya 
tesis işletilmesi ve faaliyetlerinin yürütülmesine dayandırllan” bir kusursuz sorumluluk türüdür. Bu tür işletmeler ve tesisler niteliği gereği tehlike yaratmakta ve zarar verme ihtimalini bünyesinde barındırmaktadır (Süzek, 2019: 420; Narter, 2015: 375). Bu nedenle bu tür işletme ve tesisleri işletenler ortaya çıkan zarardan uygun illiyet bağının bulunması halinde sorumlu tutulmaktadırlar.

\section{B- Kusur Sorumluluğu Görüşü}

En yaygın ve en geniş sorumluluk türü kusur sorumluluğudur (Akın, 2001: 87). Bu sorumluluk türü dar anlamda haksız fiil sorumluluğudur. Doktrinde kusur sorumluluğu kavramı, zarar veren davranışın bir kişiye (süjeye) bağlanmış olması nedeniyle "subjektif sorumluluk" olarak da kabul edilmektedir. TBK'nın 49. maddesi kapsamında, kusurlu ve hukuka aykırı bir fiille başkasına zarar veren, bu zararı gidermekle yükümlüdür. Kusur sorumluluğunun varlığı için "kusurun varlığg” temel şarttır. Tazminat yükümlülügünün varlığı için zararı meydana getiren fiilde failin şahsi kusurunun bulunması gerekmektedir. Kast veya ihmalden doğan kusur hallerinde ayrım yapılmaz. Kusur sorumluluğunda sorumluluğun doğması için kusur unsuru yanında zarar, nedensellik bağı ve hukuka aykırılık unsurlarının da bulunması gerekmektedir. Ayrıca kusur sorumluluğu kapsamında, iş yerinde iş kazası ve meslek hastalığını önlemek için 6331 sayılı Kanun ve diğer kanunlar çerçevesinde gereken özeni ve dikkati gösteren işveren kusurlu sayılmayacak ve oluşan zararlardan sorumlu tutulamayacaktır (Narter, 2015: 383-394).

\section{III- DESTEKTEN YOKSUN KALMA TAZMINATININ YASAL DAYANAKLARI}

TBK'ya göre, destekten yoksun kalma tazminatının hukuki dayanakları; "sözleşme dışı kusursuz sorumluluk halleri", "sözleşmeden doğan sorumluluk halleri" ve "vekaletsiz iş görmeden doğan sorumluluk halleri” şeklinde düzenlenmiştir (Kılıçoğlu, 2019: 267; Narter, 2015: 261).

\section{A- Sözleşme Dışı Kusursuz Sorumluluk Halleri}

Sözleşme dışı kusursuz sorumluluk hallerini, haksız fiilden kaynaklanan sorumluluk halleri ile haksız fiil dışındaki diğer sorumluluk halleri olarak ikiye ayırabiliriz. Bir kişinin diğer bir kişiye karşı hukuka aykırı ve zarar verici davranışı, haksız fiil olarak tanımlanmaktadır (Antalya, 2018: 9-10; Eren, 2019: 21-22; Karakılıç, 2017: 121). Bu noktada TBK'nın 49.maddesine göre, "kusurlu ve hukuka aykırı bir fiille başkasına zarar veren, bu zararı gidermekle yükümlüdür. Zarar verici fiili yasaklayan bir hukuk kuralı bulunmasa bile, ahlaka aykırı bir fiille başkasına kasten zarar veren de bu zararı gidermekle yükümlüdür. Söz konusu madde ve konuyla ilgili diğer maddelerde düzenlenen haksız fiil hükümlerine göre fail, destekten yoksun kalma tazminatına göre sorumlu olmaktadır (Gökyayla, 2004: 78). Haksız fiilden dolayı sorumluluk için haksız fiil failinin kural olarak kusurunun olması gerekmektedir. Destekten yoksun kalma tazminatı, haksız fiilden doğan bir tazminat türü olarak TBK'nın 53. ve 55. maddelerinde düzenlenmiş bir tazminat türüdür. TBK'nın 53. maddesinde, "ölüm halinde zararları" açıklanmış ayrıca TBK'nın 55. maddesinde, “destekten yoksun kalma zararları ile bedensel zararların hesaplama yöntemleri” hüküm altına alınmıştır (Narter, 2015: 262-263).

Haksız fiil dışında "diğer sözleşme dışı kusursuz sorumluluk" halleri de çeşitli kanunlarda düzenlenmiştir. TBK'nın; 66. maddesinde düzenlenen "adam çalıştıranın sorumluluğu”, 67. maddesinde düzenlenen "hayvan bulunduranın sorumluluğu” ve 69. maddesinde düzenlenen "yapı malikinin sorumluluğu", Karayolları Trafik Kanunu'nun 85. maddesi kapsamında "araç işletenin sorumluluğu” destekten yoksun kalma tazminatı açısından sözleşme dışı 
Destekten Yoksun Kalma Tazminatı Kapsamında Çocuğun Durumu

kusursuz sorumluluk hallerinden bazılarıdır. Bu durumlarda, sorumlunun kusuru aranmaz ve destekten yoksun kalma tazminatını ödemekle yükümlü olur (Gökyayla, 2004: 38).

\section{B- Sözleşmeden Doğan Sorumluluk Halleri}

Sözleşmeden (akitten) doğan sorumluluk hallerini; iş sözleşmesinden doğan sorumluluk halleri ve sözleşmeden doğan diğer sorumluluk halleri olarak ikiye ayırarak inceleyebiliriz.

\section{i) İş Sözleşmesinden Doğan Sorumluluk Halleri}

Sözleşmeden (akitten) doğan sorumluluğu kapsamında işveren, hizmet ilişkisinde işçinin kişiliğini korumak ve saygı göstermek ve iş yerinde dürüstlük ilkelerine uygun bir düzeni sağlamakla, özellikle iş̧̧ilerin psikolojik ve cinsel tacize uğramamaları ve bu tür tacizlere uğramış olanların daha fazla zarar görmemeleri için gerekli önlemleri almakla yükümlüdür. TBK'nın 417. maddesi kapsamında işveren, “iş yerinde iş sağllğ için gerekli her türlü önlemi almak, araç ve gereçleri noksansız bulundurmak; işçiler de iş sağllğl ve güvenliği konusunda alınan her türlü önleme uymakla yükümlüdür". İşverenin iş güvenliği tedbirlerinin almaması sonucunda işçinin iş kazası ya da meslek hastalığı nedeni ile ölümü halinde doğan maddi ve manevi zararlar için külli halefiyet ilkesi geçerlidir. TBK'nın 417/3. maddesine göre “... kanuna ve sözleşmeye aykırı davranışı nedeniyle işçinin ölümü, vücut bütünlügünün zedelenmesi veya kişilik haklarının ihlaline bağlı zararların tazmini, sözleşmeye ayklrılıktan doğan sorumluluk hükümlerine tabidir..." Söz konusu maddeye göre, işverenin gerekli önlemleri almaması nedeniyle işçinin ölmesi halinde işçinin desteğinden yoksun kalanların tazminat alacaklarının, sözleşmeye aykırılıktan doğan sorumluluk hükümlerine tabi olduğu belirtilmektedir. Ayrıca TBK'nın 417/3. maddesindeki hüküm nedeniyle destekten yoksun kalanlar, kusur ispatı ve daha uzun zamanaşımı süresi açısından sözleşmeden doğan sorumluluk hükümlerinden yararlanabilmektedirler (Narter, 2015: 267-268).

İşverenin, iş sağlığı ve güvenliğine yönelik tedbirlerini almaması, dikkat ve özen yükümlülüğünü ihlal etmesi sebebiyle meydana gelen iş kazası veya meslek hastalığı sonucu ölen işçinin desteğinden yoksun kalanların destekten yoksun kalma tazminatı talepleri borca aykırılık temeline dayanmaktadır (Gökyayla, 2004: 84).

İş kazası veya meslek hastalığından kaynaklanan destekten yoksun kalma tazminatı, işverenin özen borcuna aykırı davranması sonucu meydana gelmektedir. İşverenin iş yerinde işçisinin yaşam, sağlık ve beden bütünlügünün korunması için gerekli önlemleri alması işçisini gözetme borcunun bir gereği olarak karşımıza çıkmaktadır (Süzek, 2019: 416; Çelik, Caniklioğlu ve Bolat, 2019: 350). İşverenin 6331 sayılı İş Sağlığı ve Güvenliği Kanunu ve ilgili mevzuata göre, iş sağlığı ve güvenliğinin sağlanması için gerekli önlemleri almayarak gözetme borcuna aykırı davranması nedeniyle çalıştırdığ 1 işçisinin iş kazasına uğraması veya meslek hastalığına tutulması sonucu ölümü hâlinde desteğinden yoksun kalanlar tazminat talebinde bulunabileceklerdir (Süzek, 2019: 459; Çelik vd, 2019: 412-413; Narter, 2013: 417).

İş kazası veya meslek hastalığı sonucu işçinin bir zarara uğraması nedeniyle işverenin sorumlu olduğunun tespiti sonrasında, işverenin iş hukukundan doğan yükümlülüklerini ve/veya sözleşmelerden doğan borçlarını yerine getirmemesi nedeni ile çeşitli hukuki, idari ve cezai yaptırımlar uygulanmaktadır (Süzek, 2019: 128-132, 925-931).

\section{ii) Sözleşmeden Doğan Diğer Sorumluluk Halleri}

İş sözleşmesi dışında sözleşmeden doğan sorumluluk hallerinden birisi 6102 sayılı Türk Ticaret Kanunu'nun 914/1-2. maddesinde düzenlenen “taşıyıcının sorumluluğu” ile ilgilidir 
(Tokat, 2016: 2964-2965). Söz konusu maddeye göre, “Taşıyıcı, yolcuların kazaya uğramalarından doğacak zararı tazmin eder. Yolcunun kaza sonucunda ölmesi hâlinde, onun yardımından yoksun kalanlar uğradıkları zararın tazminini taşıyıcıdan isteyebilirler. Ancak, taşıyıcı, kazanın kendisinin veya yardımcılarının en yüksek özeni göstermelerine rağmen, kaçınamayacakları ve sonuçlarını önleyemeyecekleri bir sebepten ileri geldiğini ispat ederse tazminattan kurtulur”. Ayrıca TTK'nın 850/2. maddesine göre taşıyıcı, “taşıma sözleşmesi ile yolcuyu varma yerine ulaştırma yönünden borçlanmaktadır." Bu borca aykırılık durumunda ölüm gerçekleşmiş ise ölenin desteğinden yararlananlar, destekten yoksun kalma tazminatı talep edebileceklerdir.

\section{C- Vekaletsiz İş Görmeden Doğan Sorumluluk Halleri}

TBK'nın 526. ile 531. maddeleri arasında düzenlenen vekaletsiz iş görme, vekaleti olmayan bir kimsenin, bir başkasının işini görmesi olarak tanımlanabilir (Zevkliler ve Gökyayla, 2019: 630). Vekaletsiz işgören de zarardan sorumlu tutulabilir ve kendisine karşı TBK'nın 53/3. maddesi kapsamında destekten yoksun kalma tazminatı talebiyle dava açılabilir. Örneğin, bilinci kapalı bir hastaya, hekimin tıp biliminin kuralları çerçevesinde yapacağı müdahale TBK'nın 526. ve 527. maddelerine göre vekaletsiz iş görme olarak değerlendirilir ve hukuka uygundur (Şatır, 2015: 21). Ayrıca herhangi bir kişinin tedavi amacıyla özel bir hastaneye başvurması halinde, hastane ile hasta arasındaki hukuki ilişki "hastaneye kabul sözleşmesi” kapsamında ortaya çıkmaktadır. Bu sözleşme ilişkisi kapsamında, doktor veya sağlık personeli ile hasta arasında sözleşme ilişkisi bulunmadığı için hasta tedavi edilirken hastanın ölümü halinde özel hastane TBK'nın 116. maddesi uyarınca yardımcı kişilerin fiillerinden sorumluluk hükmü kapsamında sorumlu olmaktadır (Erol, 2017: 58-59). Ancak kişi kamu hastanesine başvurursa hastane ile arasında sözleşme ilişkisi bulunmadığı için taraflar arasında idare hukuku ilişkisi doğacaktır (Hakeri, 2020: 615).

Vekaletsiz iş görme bir sözleşme benzeridir. Vekaletsiz iş gören de zarardan sorumlu tutulabilir ve kendisine TBK'nın 53/3. maddesi uyarınca destekten yoksun kalma tazminatı talebinde bulunulabilir. Bu konu özellikle tıbbi müdahaleden doğan sorumluluk kapsamında karşımıza çıkar (Antalya, 2018: 127).

\section{D- Sözleşmeden Doğan (Akdi) Sorumluluk ile Haksız Fiil Sorumluluğunun Yarışması}

Haksız fiil sorumluluğundan, sözleşme sorumluluğundan veya kanundan doğan "sorumluluk sebepleri", sorumluluğun birden çok nedene dayanması durumunda "sorumluluk sebeplerinin yarışması" durumu ortaya çıkmaktadır (Karacabey, 1980: 668). Bu durum TBK'nın 60. maddesinde "Sebeplerin Yarışması" başlığı altında düzenlenmiştir. Söz konusu maddeye göre, "Bir kişinin sorumluluğu, birden çok sebebe dayandırllabiliyorsa hâkim, zarar gören aksini istemiş olmadıkça veya kanunda aksi öngörülmedikçe, zarar görene en iyi giderim imkânı sağlayan sorumluluk sebebine göre karar verir."

İşverenin hukuki sorumluluğu sözleşmeden kaynaklanabileceği gibi haksı fiil sorumluluğundan da kaynaklanabilir. Burada akdi sorumluluk ile haksız fiil sorumluluğu yarışmaktadır (Akın, 2001: 96). Zarar verici bir olayda hem akdi sorumluluk hem de haksız fiil sorumluluğu bulunuyorsa zarar gören, zarar vereni hangi esaslara göre sorumlu tutacağına kendi karar verir. Bu konuda zarar görenin seçimlik hakkı bulunmaktadır. TBK'nın 112. maddesine göre, "borçlu sözleşme ile üstlendiği borcu hiç veya gereği gibi ifa etmezse alacaklının bundan doğan zararlarını tazmin etmekle” yükümlüdür. Borcun hiç veya gereği gibi ifa edilmemesi halinde borçlu kusurlu kabul edilmektedir. TBK'nın 114. maddesine göre borçlu, "genel olarak sözleşmeden doğan her türlü kusurdan" sorumludur. Borçlunun bu 
sorumluluktan kurtulabilmesi için kendisine hiçbir kusurun yükletilemeyeceğini ispat etmesi gerekir (Antalya, 2018: 21). Ancak akdi sorumluluğun doğabilmesi için borçlunun sözleşmeye aykırı davrandığını, bundan dolayı zararın doğduğunu ve borcun gereği gibi ifa edilmemesi ya da hiç ifa edilmemesi ile uğranılan zarar arasında da bir illiyet bağ ispat edilmelidir.

Her iki sorumluluk türünü ispat açısından ele aldığımızda; haksız fiilden doğan sorumlulukta haksız fiile maruz kalan taraf, haksız fiilin varlığını ve doğan zararı ispat etmek zorundadır. Aksine sözleşmeden doğan sorumlulukta alacaklı ile borçlu arasındaki ilişkide borçlunun kusurlu olduğu "karine" olarak kabul edildiğinden borçlu, kusursuzluğunu ispat etmek zorundadır (Antalya, 2018: 235). Bu nedenle işverenin sorumluluğunun ispatı durumunda, sözleşmeden doğan sorumluluğun kabulü halinin haksız fiilden doğan sorumluluk halinden daha kolay bir ispat külfeti içermektedir.

Zamanaşımı süreleri açısından da haksız fiilden kaynaklı sorumluluk ile sözleşmeden kaynaklı sorumluluk arasında farklılıklar bulunmaktadır. TBK'nın 417. maddesi hükmünden doğan sözleşmeden kaynaklanan sorumlulukta zamanaşımı TBK'nın 146. maddesi hükmü uyarınca on yıllıkken, haksız fiil hükümlerinden doğan sorumlulukta TBK'nın 72. madde hükmü uyarınca iki yıllıktır. Bu kapsamda zamanaşımı hususunda da sözleşmeden doğan sorumluluk hükümlerinin uygulanması işçi lehine bir durum sağlamaktadır (Antalya, 2018: 503, 508; Oğuzman ve Öz, 2018: 73,76).

\section{IV- İŞVERNINN HUKUKI SORUMLULUĞUNDAN DOĞAN TAZMINAT DAVALARI}

İş kazası ve meslek hastalığı nedeniyle meydana gelen ölüm ve yaralanma olaylarında zarara sebebiyet veren kişilere karşı açılan rücu davaları ile ölüm sonucu destekten yoksun kalan hak sahipleri tarafından açılan tazminat davaları işverenin hukuki sorumluluğunda önemli yer tutmaktadir.

TBK'nın; 49, 53. ve 56. maddeler kapsamında maddi ve manevi zararların hukuka aykırı davranışta bulunanlar tarafından karşılanması hususunda hükümler yer almaktadır. İşte bu noktada maddi ve manevi tazminat davaları ortaya çıkmaktadır (Narter, 2015: 218-219).

\section{A- Maddi Tazminat Davaları}

İşverenin gözetimi altındayken işçinin uğradığı iş kazası ve meslek hastalıkları nedeni ile doğan bedensel zararlardan kaynaklı çalışma gücü kaybından doğan zararların tazmini, kazanç kaybından doğan zararların tazmini, ekonomik geleceğin sarsılmasından doğan zararların tazmini ve tedavi masrafları maddi tazminat davalarının konusunu oluşturmaktadır (Süzek, 2019: 428-429; Akın, 200: 100).

İşverenin iş sağlığı ve güvenliği kurallarına aykırı davranışı yüzünden zarar gören işçi veya hak sahiplerinin açtıkları maddi tazminat davaları, 5510 sayılı Sosyal Sigortalar ve Genel Sağlık Sigortası Kanunu hükümleri gereği sağlanan haklar dışında kalan zararın ödetilmesi ilkesine dayanır. Ayrıca SGK tarafından karşılanmayan zararların da tazmini maddi tazminat davası kapsamında TBK'nın genel hükümleri kapsamında sorumlu tutulan kişiden alınabilmektedir (Süzek, 2019: 423). Mevzuatımızda tazminat hesapları büyük ölçüde Yargıtay içtihatları ile belirlenmektedir.

\section{B- Manevi Tazminat Davaları}

İş kazası ve meslek hastalığı nedeni ile işçinin bedensel veya ruhsal bir zarara uğraması halinde maddi tazminat yanında koşulları varsa manevi tazminat istenebilir. Manevi tazminat 
talebinde gerekli olan koşullar; işçinin (bedensel ya da ruhsal açıdan zarara uğraması) ya da ölümü ile yakınlarının manevi zarara uğraması, zarar ile iş kazası ya da meslek hastalığı arasında uygun illiyet bağının varlığı ve hukuka aykırılık koşulunun bulunması zorunludur. İşçinin ölümü halinde ise yakınları tarafından manevi tazminat talebinde bulunulabilir (Süzek, 2019: 444). Manevi tazminat talep hakkı TBK'nın 56. maddesinde düzenlenmiştir. TBK'nın 56/1. maddesine göre "Hakim.....olayın özelliklerini göz önünde bulundurarak zarar görene uygun bir miktar paranın manevi tazminat olarak ödenmesine karar verebilir." Manevi zararı tespit edecek nesnel ölçütler bulunmadığından hakimin takdirine bırakılmıştır. Manevi zararın hukuki niteliği, öğretide değişik şekillerde tanımlansa da manevi giderim; ceza, tatmin veya telafi niteliğindedir. Yine TBK'nın 56. maddesine göre, işçinin ölümü halinde manevi tazminat davası açma hakkı tanınanlar "ölenin yakınları" şeklinde ifade edilmiştir (Balc1 vd., 2019: 19-20; Narter, 2015: 329; Balc1 vd., 2019: 19-20).

\section{C- Sosyal Güvenlik Kurumunun Rücu Davaları}

İş kazası veya meslek hastalığı sonucu zarara uğrayan veya ölen sigortalının hak sahipleri için yapılan tüm gider ve ödemeleri, sigortalının zarara uğramasına sebep olanlardan (gerek işveren gerek üçüncü şahıslardan) geri isteyebilme hakkı SGK'ya tanınmıştır (Süzek, 2019: 48-449). SGK'nın bu hakkına "rücu”, bu kapsamda işveren veya üçüncü kişiler aleyhine açılan davalara da "rücu davaları" denilmektedir (Güzel vd., 2018: 413). SGK tarafından açılacak rücu davaları 5510 sayılı Kanun'un 21. maddesinde düzenlenmiştir (Narter, 2015: 432-433; Güzel, vd., 406-408). Söz konusu maddeye göre, "iş kazası ve meslek hastalı̆̆l, işverenin kastı veya sigortalıların sağlığını koruma ve iş güvenliği mevzuatına aykırı bir hareketi sonucu meydana gelmişse, SGK sigortallya veya hak sahiplerine 5510 sayll Kanun gereğince yapılan veya ileride yapılması gereken ödemeler ile bağlanan gelirin başladı̆̆ tarihteki ilk peşin sermaye değeri toplamı, sigortalı veya hak sahiplerinin işverenden isteyebilecekleri tutarlarla sinırlı olmak üzere, SGK tarafindan işverene ödettirilir". Aynı maddenin 4. fikrasına göre, "iş kazası, meslek hastalığı ve hastalık, üçüncü bir kişinin kusuru nedeniyle meydana gelmişse, sigortallya ve hak sahiplerine yapılan veya ileride yapılması gereken ödemeler ile bağlanan gelirin başladığ tarihteki ilk peşin sermaye değerinin yarısı, zarara sebep olan üçüncü kişilere ve şayet kusuru varsa bunları çalıştıranlara rücû edilir”.

\section{V- DESTEKTEN YOKSUN KALMA TAZMINATININ KOŞULLARI}

\section{A- Desteğin Ölümü}

Destekten yoksun kalma tazminatının talep edilebilmesi için tazminat sorumlusunun hukuka aykırı bir fiil sonucunda ölmüş olması gerekir (Gökyayla, 2004: 90, Güneren, 2018: 1058, Pitırlı ve Aladağlı, 2017: 124). Bu durum sadece gerçek kişilerin ölmesi durumunda söz konusu olacaktır (Narter, 2014: 5). Herhangi bir tüzel kişilikte tüzel kişiliğin hukuken son bulmasını ifade eden fesih ve tasfiye işlemi gerçekleşse de tüzel kişi destekten yoksun kalma tazminatına konu olamaz (Kocabaş, 2014: 94). Kişi ister gelir elde etsin ister geliri bulunmayıp yardım ve hizmet etmek suretiyle destekte bulunan bir kişi olsun, destek görenlerin bu tazminatı talep edebilmesi için ölüm olayının meydana gelmesi şarttır (Kılıçoğlu, 2019: 176). Destekten yoksun kalma tazminatı hesaplanmaz. Ölümün hemen gerçekleşmesi şart değildir. Meydana gelen kaza sonucunda kişi yaralanıp, bir süre sonra kazanın etkisiyle ölmesi halinde de destekten yoksun kalma tazminatına hak kazanılır (Gökyayla, 2004: 92). Ayrıca ölüm karinesi ve gaiplik durumlarında da Türk Medeni Kanunu kapsamında belirtilen koşulların gerçekleşmesi hâlinde destekten yoksun kalma tazminatı talep edilebilmektedir (Kanbur, 2000: 30). 


\section{B- Fiil ile Zarar Arasında Uygun İlliyet Bağının Bulunması}

Sorumluluk hukukunun temel ilkesi olan uygun illiyet bağı, hayat tecrübelerine göre bir fiil ile söz konusu fiilin olayların normal akışında meydana getirebileceği zarar ile ilgili nedensellik bağıdır. Eğer destekten yoksun kalma tazminatında failin gerçekleştirdiği fiil olayların normal akışında hayat tecrübelerine göre ölüme neden olmuşsa bu durumda tazminata hükmedilebilecektir (Koçoğlu, 2017: 203). Sorumluluk hukukunda kabul edilen uygun illiyet bağı, destekten yoksun kalma tazminatının ortaya çıkma koşullarından birisidir. Diğer bir deyişle zarar veren fiil ile ölüm meydana gelmişse destekten yoksun kalma durumu gerçeklemiştir, yani fiil ile zarar arasında uygun illiyet bağı vardır (Güneren, 2018: 670).

\section{C- Desteğin Bakım Gücüne Sahip Olması}

Destek kavramı, bir başkasının bakımını fiilen ve düzenli biçimde karşılıksız olarak sağlayan ya da ölmemiş olsaydı bunu sağlaması kuvvetle muhtemel kendisinden beklenen kişi olarak tanımlanabilir (Eren, 2019: 755, Süzek, 2019: 439). Destek ile desteğini yitiren arasındaki desteklik ilişkisi, gerçek destek veya farazi destek olmak üzere ikiye ayrılmaktadır (Narter, 2015: 260). Ölüm veya benzeri hukuki sonuç doğuran olay gerçekleştiği anda başkasına fiili ve düzenli bir şekilde bakan kişi gerçek destek olarak tanımlanmaktadır (Gökyayla, 2018: 99). Eşlerin birbirlerine, çocukların anne-babalarına, kardeşlerin birbirlerine destek olması gerçek destek sayılmaktadır. Diğer yandan ölüm anında destek veya destek görenin arasında bakım ilişkisi bulunmamasına rağmen ölmeseydi ileride bakması kuvvetle muhtemel olan kişi farazi destek olarak nitelendirilmektedir. Farazi destek olarak küçük yaştaki henüz çalışma çağına gelmemiş öz veya üvey evlatlar sayılabilir (Antalya, 2018: 471). Ölen kişi ile destek alan kişiler arasında kan hısımlığı ya da mirasçılık gibi başka bir unsurun bulunması şart değildir.

Çocuğun anne ve babalarına destekliği, destek biçimlerinden bir tanesidir. 18 yaşına kadar kişiler istisnai hallerle ergin kılınmadıkça, çocuk sayılır. Ölen çocuğun, gelecekte anne ve babasına bakacağı, yardım edeceği beklenebiliyorsa çocuk, anne ve baba için farazi destektir (Karahasan, 2003: 1314). Çocuğun anne ve babasına destekliği ile ilgili doktrinde iki farklı görüş bulunmaktadır. Doktrindeki baskın görüşe göre, çalışma yaşına gelmemiş çocuğun ölmesi halinde, anne ve babanın destekten yoksun kalma tazminatını talep edebilmeleri, yaşamın ve olayların olağan akışı içinde ileride çocuklarının bakımına ihtiyaç duymalarına ve çocuğun da bakım gücüne kavuşabileceğinin beklenebilir olmasına bağlıdır (Karahasan, 2003: 130). Yargıtay da, çocukların ileride destek olmaları ihtimalinin, anne ile babanın ileride bakım ihtiyacı içinde olup olmayacağı konusunda ispat edilebilmesiyle mümkün olduğu görüşündedir (Tekinay vd, 1993: 29). Çocuğun ileride bakım gücüne kavuşacağı ihtimali ile birlikte anne ve babanın bakım ihtiyacı içinde olacağı belirlendikten sonra çocuğun destekliği kabul edilebilir hale gelerek anne ve baba lehine destekten yoksun kalma tazminatına hükmedilebilir (Gökyayla, 2004: 128).

Yargıtay'ın kararlarına göre, çocuk büyüdüğünde anne ve babasının belirli bir düzeyde desteği olur. Bu destek tutar bakımından değişebilirse de çocuğun anne ve babasına hiç destek olamayacağı kabul edilemez (Güleç Uçakhan, 2017: 663).

Çalışmamızın konusunu oluşturan ve içtihat birliği sağlayan 22.06.2018 tarihli E.2016/5 K. 2018/6 sayılı Yargıtay İçtihadı Birleştirme Büyük Genel Kurulu Kararında, “..hayatta olduğu süre boyunca sürekli ve düzenli olarak annesine ve babasına bakan veya ĕger ölüm gerçekleşmiş olmasaydı az çok yakın bir gelecekte bu bakımı sağlayacak olan çocukların anne-babası için destek oldukları" belirtilmiştir. Yine söz konusu kararda “.... Ayrrca çocuk ile anne-baba arasındaki yardım ilişkisinin 4721 sayılı TMK'nın 322. Maddesine göre bir yükümlülük olarak belirtilmiştir.... Öte yandan çocuğun nafaka yükümlülüğünü düzenleyen 
TMK'nın 364. maddesine göre, herkes, yardım etmediği takdirde yoksulluğa düşecek olan üstsoyu ve altsoyu ile kardeşlerine nafaka vermekle yükümlüdür. TMK ile belirlenen bu yükümlülükler, çocuklarının ölümü ile anne veya babanın bir desteği kaybettiklerinin kolaylıkla kabul edilmesi sonucunu doğuracaktır. Çocuğun, anne babasının desteği olabilmesi için öncelikle bakım gücünün bulunması gerekmektedir. Bakma para ve para ile ölçülebilecek bir klymet olabileceği gibi bir hizmet ifası veyahut benzeri yardımlar şeklinde de olabilir. Gerçekten de çocuğun annesine-babasına gündelik yaşamında ya da her türlü hastalık ve sair sıkıntısında yardımcı olması maddi destek kapsamında değerlendirilmelidir. Bu nedenle çocuğun nakdi gücünün bulunmaması annesine-babasına maddi bir destek olmayacağı ya da ileride olamayacağı sonucunu doğurmayacaktır. Nitekim genel yaşam deneyimleri çocuğun annesine-babasina her koşulda ve belirli bir düzeyde hayatta olduğu sürece ya da gelecekte sürekli ve düzenli olarak destek olacağını gösterir. Bu desteğin miktarl tarafların yaşam düzeyi, sağlık, sosyal ve ekonomik durumları ile orantılı olarak değişebilirse de çocuğun hiç destek olmayacă̆ kabul edilemez. Diğer taraftan destekten yoksun kalma tazminatından bahsedilebilmesi için ikinci olarak anne-babanın bakım ihtiyacı bulunmalıdır. Destek olan veya olacak olan çocuk tarafindan bakılan anne-babanın, çocuklarının ölümü ile çocuğun yardımından kısmen veya tamamen yoksun kalması, bu sebeple muhtaç olması veya ileride muhtaç duruma düşecek olması gerekmektedir. ....Desteğin ölümü sonucunda, tazminat talep eden annenin-babanın kendi sosyal seviyelerine uygun olarak yaşamaları güçleşmişse, destekten yoksun kalındığı kabul edilmelidir. Anne-babanın destekten yoksun kalmış sayılabilmesi için zaruret durumuna düşmesi, en zaruri ihtiyaçları dahi karşılayamaz hâle gelmesi gerekli değildir. Anneninbabanın geliri bulunabilir, varlıklı olabilir, çocuğunun nakdi olarak bakımına ihtiyaç duymayabilir, ancak bu durum annenin-babanın, çocuğun ölümü nedeniyle çocuğun hizmet ifasından veyahut benzeri yardımlarından mahrum kalmadı $\breve{g}$, sosyal seviyesine uygun olarak yaşamının güçleşmediği, diğer bir ifadeyle çocuğun desteğinden mahrum kalmadı̆̆ ya da kalmayacağ̀ sonucunu doğurmayacaktır. Her annenin-babanın, çocuğun ölümü ile onun desteğinden yoksun kalacă̆ kabul edilmelidir. "'

Destekten yararlananın, destekten yoksun kalma tazminatına hak kazanabilmesi için aynı zamanda bakım ihtiyacının da bulunması gerekir. Yargitay HGK, 21.04.1982 gün, 1979/41528 E.,1982/412 K. sayılı kararına göre, “...bakım ihtiyacl, sosyal düzeye uygun olan yaşamın devamını sağlamak için gerekli olanaklardan yoksun kalmayı anlatır. Ĕger ölenin eylemli olarak baktığı davacı, ölüm yüzünden bu bakımın sağladı̆̆ yaşama düzeyinin altına düşmüş olursa, ihtiyaç bulunma koşulu gerçekleşmişs sayllır. Diğer bir ifadeyle, destekten faydalananın yaşamakta olduğu ve hâline uygun bulunan hayat tarzında bozucu bir etkiye uğraması bakım ihtiyacı bulunduğunun kabulünü gerektirmektedir."

Bakma eyleminin gerçekleşebilmesi için desteğin bakım gücüne sahip olması gerekmektedir. Diğer bir ifadeyle, ölümün gerçekleştiği anda veya ileride bakım gücü olmayan destek, desteğinden yararlanan için destek sayılamayacaktır. Bakma kavramının içeriği hususunda Kanunda herhangi bir biçim öngörülmemiştir. Bakma para ve para ile ölçülebilecek bir kıymet olabileceği gibi bir hizmet ifası veyahut benzeri yardımlar şeklinde de olabilir. Bu nedenle desteğin yardımının yalnızca parasal nitelikte olması, bakım gücünün varlığı için bir şart değildir (Güneren, 2018: 1062).

Bakım gücü kavramı, parasal güç ve zenginlikle sınırlandırılmıştır. Genel olarak bakım gücü, bir kimsenin kendi ihtiyaçlarını karşılayıp geliri ile orantılı olarak miktar tasarruf yaptıktan sonra yardımda bulunacağ 1 kimselere gelirinden bir pay ayırabilmesi veya bu kimselere fiilen sürekli ve düzenli şekilde yardım ve hizmet etmek suretiyle bu kimselere ekonomik menfaat sağlayarak destek olabilmesidir (Seratl1, 2003: 90). 
Bakım ihtiyacı, desteğin ölümü nedeniyle desteğini yitirenin sosyal seviyesine uygun bir yaşam seviyesinin maddi anlamda kaybedilmesidir. Yargıtay'ın yerleşik kararlarında,

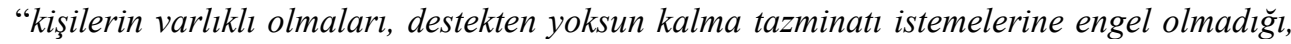
varlıkl olan kişilerin ilerde yoksulluğa düşmeyeceklerini söylemek olanaksız olduğu gibi varlıkl olsalar bile, ölen kişinin yardım ve hizmet yoluyla să̆layacă̆ desteklikten yoksun kaldıkları için her durumda tazminat isteme haklarının olduğu" belirtilmektedir (Çelik, 2016: 33). Bakma, çeşitli tarzlarda veya muhtevalarda olabilir: para vererek, yiyecek, elbise, mesken sağlayarak, okuma masraflarını karşılayarak veya artık iyileşme ümidi kalmayan yatalak bir hastanın doktor ve hastabakıcı ücretlerini ödemek suretiyle yapılan yardımlar hep bakma sayılır. Yardımlar, para yoluyla olabileceği gibi hizmet görülmesi şeklinde de olabilir (Oğuzman vd., 2018: 534).

Anne ve babanın bakım ihtiyaç süreleri de önemli bir konudur. Çocuğun, ölümü tarihinde anne babası için gerçek destek olması halinde, bakım ihtiyaç süresi çocuğun ölüm tarihinden, anne babanın ölüm tarihine kadar devam etmektedir. Zira anne babanın bakım ihtiyacı süresi çocuğun bakım gücü süresinden önce dolacaktır (Gökyayla, 2004: 189, Çelik, 2016: 126). Ölüm tarihinde çocuğun henüz bakım gücüne sahip olmaması, yani farazî destek ilişkisinin bulunması halinde çocuğun bakım gücüne sahip olduğu tarih ile anne babanın bakım ihtiyacı içerisine düşeceği tarihten sonra olanı destek ilişkisinin doğduğu tarihtir (Çelik, 2016: 143). Farazî destek ilişkisinde, çocuğun gelecekte evlenmesi, çocuk sahibi olması gibi hallerde bakım gücünün azalabileceği veya ekonomik durumunda zamanla iyileşme olup bakım gücünün artabileceği ihtimâllerinin de dikkate alınması gerekmektedir (Kocabaş, 2014: 291). Çocuğun üvey anne ve babası ile destek ilişkisi kurması halinin öz anne babayla kurulan destek ilişkisinden farkı bulunmamaktadır. Zira destek ilişkisi yakınlık derecesi yerine fiili duruma göre tesis edilmektedir (Gökyayla, 2004: 288).

Uygulamada, çocuğun bakım gücüne sahip olabileceği en erken yaş on sekiz olarak kabul edilmektedir (Çelik, 2017: 141-142).

\section{V- DESTEKTEN YOKSUN KALMA TAZMINATININ SOSYAL GÜVENLİK MEVZUATI ILE İLŞKILLENDİRILMESİ}

\section{A- Genel Olarak}

İş kazası nedeniyle talep edilebilecek destekten yoksun kalma tazminatının belirlenmesinde etkili olan faktörlerden birisi de rücu edilebilen sosyal güvenlik ödemeleridir. Sosyal güvenlik ödemelerinin, indirim işlevi görebilmesi onun sorumluluğu doğuran olaya neden olanlara rücu edilebilmesine bağlıdır. 5510 sayılı Sosyal Sigortalar ve Genel Sağlık Sigortası Kanunu'nun 21/1. maddesinde de rücu edilebilecek sosyal güvenlik ödemelerinin kapsam1 belirtilmiştir. Maddeye göre, "iş kazası ve meslek hastalığ , işverenin kastı veya sigortalıların sağlı̆̆ını koruma ve iş güvenliği mevzuatına aykırı bir hareketi sonucu meydana gelmişse, Kurumca sigortallya veya hak sahiplerine bu Kanun gereğince yapılan veya ileride yapılmasl gereken ödemeler ile bağlanan gelirin başladı̆̆ı tarihteki ilk peşin sermaye değeri toplamı, sigortalı veya hak sahiplerinin işverenden isteyebilecekleri tutarlarla sinırl olmak üzere, Kurumca işverene ödettirilir” hükmü getirilmiştir. 5510 sayılı Kanun'un 21. maddesi kapsamında Sosyal Güvenlik Kurumu (SGK) tarafından rücu edilebilen ödemeler dışında kalan ve rücu edilemeyen sosyal güvenlik ödemeleri bu tazminatlardan indirilemeyecektir.

Anayasa Mahkemesinin 28.11.2013 tarih ve 2013/74 E., 2013/143 K. sayılı kararına göre, “...bir iş kazası nedeniyle belirli bir süre çalışamayacak olan sigortalı işçiye ekonomik bir güvence sağlamak amacıyla 5510 sayılı Kanun gereğince yapılan yardımlar sosyal devlet olmanın gereği olup işveren veya üçüncü kişilerin iş kazası nedeniyle iş̧̧iye karşı sorumlu oldukları tazminat borcunu ikame amacı taşımamaktadır. Bu nedenle, iş kazasından zarar 
gören sigortalı işçi veya hak sahibi yakınlarınca, kazada sorumluluğu bulunanlar aleyhine açılan tazminat davalarında, işveren veya üçüncü şahıslara rücu edilemeyen sosyal güvenlik ödemelerinin zarar veya tazminattan indirilmemesine yönelik kuralda sosyal hukuk devleti ilkesi ile çelişen bir yön de bulunmamaktadır."

Sigortalının sürekli iş göremezlik geliri almakta iken ya da iş kazası veya meslek hastalığ 1 sonucu hayatını kaybetmesi sonucu sigortalının hak sahiplerine bağlanan gelir ölüm geliri olarak tanımlanmıştır. Ölen sigortalıların hak sahiplerine ölüm geliri bağlanması için sigortalılık süresi, yaş veya prim ödeme gün sayısı gibi koşullar bulunmamaktadır. Kişi sigortalı olarak ilk defa çalışmaya başladığı gün iş kazası veya meslek hastalığı sonucu hayatını kaybettiği takdirde bile hak sahiplerine ölüm geliri bağlanmaktadır. (Tuncay ve Ekmekçi, 2019: 443). 5510 sayılı Kanun'un 3/1. maddesinde, “...sigortalının veya sürekli iş göremezlik geliri ile malullük, vazife malullüğü veya yaşlılık ayliğı almakta olanların ölümü halinde, gelir veya aylık bağlanmasına veya toptan ödeme yapılmasına hak kazanan eş, çocuk, anne ve baba hak sahibi olarak" ifade edilmişlerdir. Görüldüğü üzere 5510 sayılı Kanunda sigortalının iş kazası ya da meslek hastalığı sonrasında ölümü durumunda kendilerine gelir bağlanacak hak sahipleri içerisinde ölenin anne ve babası da belirtilmiştir. Ancak anne-babanın gelirden yararlanma hakk1 5510 sayılı Kanunda belirtilen birtakım şartların bir arada bulunmasına bağlıdır. 5510 sayılı Kanun'un 34/1-d maddesinde, anne ve babanın aylığa hak kazanması düzenlenmiştir. Söz konusu maddede, "..hak sahibi eş ve çocuklardan artan hisse bulunması hâlinde her türlü kazanç ve irattan elde etmiş olduğu gelirinin asgari ücretin net tutarından daha az olması ve diğer çocuklarından hak kazanılan gelir ve aylıklar hariç olmak üzere gelir ve/veya aylık bağlanmamış olması şartıyla ana ve babaya toplam \% 25 'i oranında; ana ve babanın 65 yaşın üstünde olması hâlinde ise artan hisseye bakılmaksızın yukarıdaki şartlarla toplam \% 25'i oranında aylık bağlanır" şeklinde düzenleme yapılmıştır. 5510 sayılı Kanun'a göre, anne ve babanın ölüm gelirine hak kazanabilmesi için sigortalının ölüm tarihinde eş ve çocuklara bağlanması gereken gelirden artan bir pay bulunması, her türlü kazanç ve irattan elde etmiş oldukları gelirin asgari ücretin net tutarından daha az olması ve son olarak diğer çocuklarından hak kazanılan gelir ve aylık hariç olmak üzere gelir ve/veya aylık bağlanmamış olması gerekmektedir (Güzel, vd. 2018: 400). Eğer anne ve baba 5510 sayılı Kanun'da belirtilen söz konusu şartları sağlayamazsa ölüm gelirine de hak kazanamayacaklardır.

Yargıtay 21. Hukuk Dairesinin istikrar kazanmış kararlarına göre, “iş kazası veya meslek hastalı̆̆ sonucu ölen sigortalı işçinin desteğinden yoksun kalan anne ve babast, sigortalı bir işte çalışlyorlarsa ya da sosyal güvenlik kurumlarından gelir veya aylık allyorlarsa Sosyal Güvenlik Kurumu tarafindan onlara gelir bağlanmayacağından, ölen çocuğundan dolayı destekten yoksun kalma tazminatı talep edememektedirler” (Çelik, 2016: 84-85).

Yargıtay 21.HD'nin konu ile ilgili istikrar kazanmış bu görüşü; TBK'nın 54/2. maddesine ve 55. maddesine aykırı olduğu ayrıca bu kararların Anayasanın eşitlik ilkesine ve Yargıtay Hukuk Genel Kurulunun 17.10.1973 tarih 1971/4-899 E. -1973/798 K. sayılı kararına da aykırı olduğu yönünde eleştirilmiştir (Çelik, 2016: 85-86).

\section{B- Ölen Çocuğun Anne ve Babasına Desteklik İlişkisinin Karine Olarak Kabul Edilmesi}

Haksız fiil nedeniyle ölen çocuğun anne ve babasının destekten yoksun kalma tazminatı talep edebilecekleri yönünde Yargıtay Hukuk Genel Kurulu görüş yazısında özetle; “...... iş kazası veya meslek hastalığ sonucu vefat eden işçinin anne ve babasının destekten yoksun kalma tazminatı zararının varlı̆̆ının 5510 sayılı Sosyal Sigortalar ve Genel Săglık Sigortası Kanunu'nun 34. maddesindeki şartların gerçekleşmiş olması koşuluna bağlanması yönündeki Yargıtay 21. Hukuk Dairesi görüşü ile haksız fiil sonucu vefat edenin anne 
Destekten Yoksun Kalma Tazminatı Kapsamında Çocuğun Durumu

babasının destekten yoksun kalma tazminatının varlığının Türk Borçlar Kanunu'nun 53. maddesi gereğince değerlendirilerek, somut olayın özellikleri dikkate alınarak fiili bir karine olarak anne ve babaya her hâlde destek olduğunun kabul edilmesi gerektiği yönündeki Yargitay 4., 11. ve 17. Hukuk Dairesi kararları arasında özellikle anne ve babanın destek zararlarının değerlendirilmesi konusunda içtihat farklılı̆̆ının bulunduğu, içtihatların birleştirilmesi gerektiğine” karar verilmiş ve konuyla ilgili 14.11.2018-30595 tarih-sayılı Resmi Gazete'de yayınlanan 22.06.2018 tarihli E.2016/5 K. 2018/6 sayılı Yargıtay İçtihadı Birleştirme Büyük Genel Kurulu Kararı ile içtihat birliği sağlanmıştır.

Söz konusu görüş aykırılığının giderilmesi talebine konu olan kararlarda belirtilen Yargıtay Dairelerinin görüşleri aşağıda özetlenmiştir. Buna göre;

1) Yargıtay 4. Hukuk Dairesi görüş yazısında özetle; “uzun yıllar boyunca uygulamalarının "genel yaşam deneyimleri ve hayatın olağan akışl yetişkin bir insanın anne-babasına her hâlükârda ve belirli düzeyde destek olacă̆ yönünde olduğu, 21. Hukuk Dairesi dışındaki diğer dairelerin görüşlerinin de aynı doğrultuda bulunduğu, Dairelerinin görüşleri doğrultusunda içtihat aykırılığının giderilmesinin gerektiğini” belirtmiştir.

2) Yargitay 11. Hukuk Dairesi görüş yazısında özetle; “ölen desteğin, sağllğında, talepte bulunanlara destek olup olmadiğının uyuşmazlık konusu olması hâlinde, bu durumun saptanmasında somut olayın özelliklerinin ve fili karinelerin dikkate alınmasl gerektiği, Yargitay 11. Hukuk Dairesi kararlarında destek tazminatı isteminde bulunan anne ve babaya, ölen evladın her halükarda ve belli biçimlerde de olsa maddi destek sağladiğının fiili bir karine olarak kabul edildiği, Yargıtay 21. Hukuk Dairesinin görevine giren davalar bakımından ise uyuşmazlığa konu destek kavramının somut olgularla ortaya konması yerine sosyal güvenlik hukuku bağlamında belirgin bir kriter olarak ortaya çıkan ana-babaya Sosyal Güvenlik Kurumundan aylık bağlanması olgusuna değer izafe edildiği, bu nedenle içtihatların birleştirilmesinin yerinde olacağını" öne sürmüştür.

3) Yargıtay 17. Hukuk Dairesi görüş yazısında özetle; “ bir kimsenin ücretsiz olarak diğer bir kimsenin kısmen ve tamamen bakımını üstlenmesine destek denildiği, çocukların, çalışma çă̆ında ve gelir sahibi ise ana babaya destek olabilecekleri, yine bakım ihtiyacının yoksulluk anlamına gelmediği gibi bu tazminatı isteyenlerin maddi durumu ne derece iyi olursa olsun bir gün zarurete düşüp düşmeyecekleri ve ölenin yardımına muhtaç olup olmayacaklarını önceden kestirmenin ve bu konuda kesin bir yargiya varılmasinın mümkün bulunmadiğl, destek tazminatında Sosyal Güvenlik Kurumunca ölüm aylığı kaleminden bağlanan dul ve yetim aylıklarının sigortalının sağlığında belli prim ödemesi karşılığında olup, bunun dahi rücu edilemeyecek yararlardan olduğundan destek tazminatından indirilmeyeceği, somut taleple ilgili olarak anne ve baba destek tazminatı talep edebileceklerinden, Yargitay 4. Hukuk Dairesi, Yargıtay 11. Hukuk Dairesi ve Yargıtay 17. Hukuk Dairesi içtihatları doğrultusunda içtihatların birleştirilmesi gerektiğini” belirtmiştir.

4) Yargıtay 19. Hukuk Dairesi görüş yazısında, “destek tazminatı ile ilgili konuların uzun süreden beri Dairelerinin görevi dışında olduğundan bu konuda bir görüş bildirme olană̆ bulunamadiğını" ifade etmiştir.

Konuyla ilgili olarak Yargıtay 21. Hukuk Dairesinin içtihadı birleştirmenin gerekliliği noktasında “....iş kazası veya meslek hastalı̆̆ nedeniyle sigortalı işçinin ölümü üzerine anne ve babanın talep ettiği destekten yoksun kalma tazminatı talebiyle ilgili olarak, iş kazast veya meslek hastalığı nedeniyle ölüm hâlinde açılan destekten yoksun kalma tazminatı davalarında sorumluluğun işverene ait bulunduğu ve işverenin sorumluluğunun 6331 sayılı

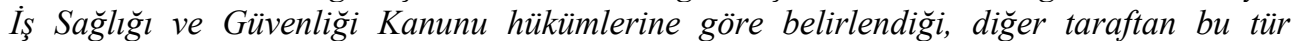
davalarda SGK tarafindan bağlanan gelirlerin peşin sermaye değerinin rücuya tabi kısmının hükmolunacak tazminattan indirilmesinin yasal bir zorunluluk olduğu ve anne-babaya gelir 
bağlanıp bă̆lanmadı̆̆ının tespitinin uyuşmazlı̆̆ın çözümünde önem arz ettiği, bu nedenle içtihat farklılı̆̆ı olduğu belirtilen Yargıtay 21. Hukuk Dairesi kararlart ile diğer Özel Daire kararları arasında konu bakımından farklılık bulunduğu belirtilerek içtihadı birleştirmeye gerek olup olmadı̆̆ ön sorun olarak gündeme getirilmiştir. Ön soruna ilişkin yapılan değerlendirmede; ...i is kazast veya meslek hastalığından kaynaklanan destekten yoksun kalma tazminatı ile diğer Özel Dairelerde görülen destekten yoksun kalma tazminatı davaları arasında konu bakımından farklılık bulunmadığ belirtilerek içtihatların birleştirilmesi gerektiğine" karar verilmiştir.

Yargıtay İçtihadı Birleştirme Büyük Genel Kurulu Kararında çok açık bir şekilde "annebabaya bağlanacak ölüm geliri ile destekten yoksun kalma tazminatı hem kaynağını aldıkları mevzuat hem de içeriği olarak birbirinden farklı kavramlar olduğu, annenin-babanın ölüm gelirine hak kazanması veya koşulları oluşmadiğından ölüm gelirine hak kazanamaması destekten yoksun kalma tazminatı talep etmesine bir engel oluşturmadığl" belirtilmiştir. Söz konusu kararda özet olarak “...anneye-babaya ölüm geliri bağlanmamış olması anneninbabanın çocuklarının bakımına ihtiyaçları bulunmadı̆̆ sonucunu doğurmayacaktır... anneye-babaya ölüm geliri bağlanmamış olması destek ilişkisinin ve buna bağll olarak destekten yoksun kalma tazminatı talep hakkının varlığına bir engel oluşturmayacaktır. Ayrıca anne-babaya ölüm geliri bağlanmış olması da çocuk ile anne-baba arasındaki destek ilişsisinin varlı̆̆ ve annenin-babanın destekten yoksun kalma tazminatına hak kazanabilmesi için öngörülen bir şart değildir...anneye-babaya ölüm geliri bağlanmast veyahut bağlanmaması tamamen sosyal güvenlik mevzuatına göre belirlenen bir konudur ve destek ilişkisinin var olup olmadı̆̆ının ispatında bir şart olarak gözetilemeyecektir. Anne ve babanın belirli bir gelirinin olması, ölenin desteğinden yoksun kalmadıkları sonucunu doğurmayacaktır...anne-baba tarafindan çocuğunun haksız fiil ve/veya akde aykırıllı sonucu ölmesi nedeniyle açılan destekten yoksun kalma tazminatı davalarında, desteklik ilişkisinin varlı̆̆ının ispatı için Sosyal Güvenlik Kurumundan gelir bağlanması şartı aranmayacă̆ şeklinde hükme varılmıştır.

Söz konusu karara karşı oy gerekçesinde özetle “...destekten yoksun kalma tazminatının talep edildiği bir davada davacılar destek ilişkisinin ve zararın varlı̆̆ yani destekten yoksun kalındığ ve bakım ihtiyacını ispat etmelidirler. ...sonuç olarak İçtihadı Birleştirme Kararı; açıkça TBK'nın 50. maddesini ortadan kaldırmaktadır. Ana ve babanın destekten yoksun kalma nedeniyle bundan önce açtıklarl ve devam eden ve bundan sonra açacakları maddi tazminat davalarının tamamının kabul edilmesi gerektiği yönünde bir sonuç doğuracaktır... Ana ve babanın karine olarak destek göreceklerinin kabulü ise kendi gelirleri bulunduğundan bu delil karşısında ortadan kalkacaktır. Ana ve babanın bu durumda ispat yükü altında olacakları da ortadadır. Zaten, desteğin olmadı̆̆ gibi olumsuz bir durumun davalı tarafindan başka delillerle kanitlanmasının beklenmesi hakkaniyete uygun değildir...mevzuatta açıkça düzenlenen konuya ilişsin olduğundan, bu İçtihadı Birleştirme Karart yok hükmündedir ve uygulamada bir değişikliği gerektirmeyecektir.” şeklinde ifade edilmiştir.

Kanaatimizce, 21.HD’nin destekten yoksun kalma tazminatının mahiyeti ile ilgili söz konusu farklı görüşü, SGK'dan aylık bağlama koşulları ile destekten yoksun kalma koşullarını karıştıran bir anlayıştan doğmuştur. Yargıtay 21.HD'nin farklı görüşü çerçevesinde yıllardır verdiği kararları yansıtan karşı oy gerekçesine yer alan açıklamalar ile Yargıtay 4. HD, 11. HD ve 17.HD’nin görüşlerinin bir içtihat birliğine dönüşmesi zorunlu hale gelmişti. Söz konusu içtihat kararı ile çocuğunun haksız fiil ve/veya akde aykırılık sonucu ölmesi nedeniyle anne-baba tarafından açılan destekten yoksun kalma tazminatı davalarında, desteklik ilişkisinin varlığının ispatı için SGK'dan gelir bağlanması şartının aranmamasının gerektiği çok önemli bir karar niteliğindedir. 


\section{SONUÇ}

Yargıtay 21. Hukuk Dairesinin kararlarına göre, iş kazası veya meslek hastalığı sonucu ölen sigortalı işçinin desteğinden yoksun kalan anne ve babası, sigortalı bir işte çalışıyorlarsa ya da sosyal güvenlik kurumlarından gelir veya aylık alıyorlarsa ölen çocuğundan dolayı destekten yoksun kalma tazminatı isteyememekte ve böylece zarar sorumluları tazminat ödememekteydiler. Konuyla ilgili olarak “22.06.2018 tarihli E.2016/5 K. 2018/6 sayılı Yargıtay Içtihadı Birleştirme Büyük Genel Kurulu Kararl” ile içtihat birliği sağlanarak annebabanın, çocuğunun haksız fiil ve/veya akde aykırılık sonucu ölmesi nedeniyle açtığı destekten yoksun kalma tazminatı davalarında, desteklik ilişkisinin varlığının ispatı için SGK'dan gelir bağlanması şartının aranmayacağına ayrıca anne-babanın çocuğunun haksız fiil ve/veya akde aykırılık sonucu ölmesi nedeniyle açtığı destekten yoksun kalma tazminatı davalarında, çocukların anne-babaya destek olduklarının karine olarak kabulünün gerektiğine karar verilerek çok önemli bir mağduriyet ortadan kaldırılmıştır.

\section{Kaynakça}

Akın, L. (2001). Işs Kazasından Doğan Maddi Tazminat. Ankara: Yetkin Yayınları.

Antalya, O. G. (2018). Borçlar Hukuku-Genel Hükümler. C.1. İstanbul: Legal Yayınc1lık.

Balcı, M., Soner, B., Aydoğan, B. ve Yener, A. (2019). İs Kazalarl ve Meslek Hastalıklarından Kaynaklanan Manevi Tazminat Davaları. Ankara: Yetkin Yayınları.

Çakırca, S. İ. (2012). Türk Sorumluluk Hukukunda Yansıma Zararl. İstanbul: Vedat Kitapçılık.

Çelik, A. Ç (2016). Ölüm Nedeniyle Destekten Yoksunluk. Ankara: Seçkin Yayıncılık

Çelik, N., Caniklioğlu, N. ve Canbolat, T. (2019). İş Hukuku Dersleri. İstanbul: Beta Yayınları.

Eren, F. (2019). Borçlar Hukuku Genel Hükümler. Ankara: Yetkin Yayınları.

Erol, H. G. (2017). Özel Hastanelerin Hukuki Sorumluluğu ve Hasta Hakları. Ankara: Seçkin Yayınc1lik.

Gökyayla, K. E. (2004). Destekten Yoksun Kalma Tazminatı. Ankara: Seçkin Yayıncılık.

Güleç Uçakhan, S. (2017). Maddi Tazminat Esasları ve Hesaplanması. Ankara. Seçkin Yayınc1lık.

Gündüz, F. E. ve Gündüz, H. (2011). İdare Hukukunda Destekten Yoksun Kalma Tazminatı. Gazi Üniversitesi Hukuk Fakültesi Dergisi. 15 (3). 230-232
Güneren, A. (2018). İş Kazası ve Meslek Hastalı̆̆ından Kaynaklanan Maddi ve Manevi Tazminat Davaları. Ankara: Adalet Yayınevi.

Güzel, A., Okur, A.R. ve Caniklioğlu, N. (2018). Sosyal Güvenlik Hukuku. İstanbul: Beta Yayıncilık.

Hakeri, H. (2020). Tip Hukuku. Ankara: Seçkin Yayıncilik.

Kahveci, N. (2002). Sorumluluk Hukuku Açısından Zarar Görenin Kusurunun Hukuki Sonuçları. Dinbilimleri Akademik Araştırma Dergisi II. 3(131).

Kanbur, Z. (2000). Ölüm ve Cismani Zararlarda Tazminat Alacaklıları. Yayınlanmamış Yüksek Lisans Tezi. Gazi Üniversitesi SBE. Ankara.

Karacabey, Ö. F. (1980). Hakların Yarışması. Ankara. Ankara Barosu Dergisi. 6(668).

Karahasan, M. R. (2003). Türk Borçlar Hukuku Genel Hükümler. C.1. İstanbul: Beta Yayınları.

Karakılıç, H. (2017). Borçlar Hukuku Genel Hükümleri. İstanbul: On İki Levha Yayıncılık.

Kıcalıoğlu, M. (2015). Haksız Fiillerden Doğan Tazminat Davaları. Ankara: Yetkin Yayınları.

Kilıçoğlu, M. (2019). Destekten Yoksun Kalma Tazminatı. Ankara: Bilge Yayınevi.

Kocabaş, G. (2014). Destekten Yoksun Kalma Tazminatının Unsurları. Marmara Üniversitesi Hukuk Fakültesi Hukuk Araştırmaları Dergisi. 20(3). 4-5 . 
Koçoğlu, S. (2017). İş Kazası ve Meslek Hastalıkları Sonucu Destekten Yoksun Kalma Tazminatının Şartları. Kafkas Üniversitesi Sosyal Bilimler Enstitüsü Dergisi. 19(3). 191192.

Koçhisarlıoğlu, C. (2004). Kusur İşleme Ehliyeti Olarak Ayırt Etme Gücünün Haksız Eylem Alanında Derecelendirilmesi. Ankara Üniversitesi Hukuk Fakültesi Dergisi. 53(4).

Narter, S. (2015). Işs Kazası ve Meslek Hastalı̆̆ında Hukuki ve Cezai Sorumluluk. Ankara: Adalet Yayınevi.

Oğuzman, K. ve Öz, T. (2018). Borçlar Hukuku Genel Hükümler. C.2. İstanbul: Vedat Yayıncilik.

Pitırlı, B. ve Aladağlı, A. (2017). Destekten Yoksun Kalma Tazminatı. Bahçeşehir Üniversitesi Hukuk Fakültesi Dergisi. 12(155156). $115-163$.

Seratlı, G. B. (2003). İş Kazasindan Doğan Destekten Yoksun Kalma Tazminatı. Ankara: Yetkin Yayınları.

Seven, V. (2017). Sigorta Güvence Hesabının Kapsam1 ve Destekten Yoksun Kalma Tazminat1. Bahçeşehir Üniversitesi Hukuk Fakültesi Dergisi. 12(157-158).55.

Süzek, S. (2019). İş Hukuku. İstanbul: Beta Yayınlar1.

Şatır, N. (2015). Emsal Kararlar Işı̆ğında Kamu ve Özel Hastanelerde Çalışan Hekimlerin Hukuki ve Cezai Sorumluluğu. YargıtayDanıştay İçtihatları. Ankara: Yetkin Yayınları.

Tekinay, S. S., Akman, S., Burcuoğlu, H. ve Altop, A. (1993). Borçlar Hukuku Genel Hükümler. İstanbul: Fakülteler Matbaası.

Tokat, H. (2016). Karayoluyla Yolcu Taşımacılığından Kaynaklanan Akdi Sorumluluk. Ankara Üniversitesi Hukuk Fakültesi Dergisi. 65(4). 2016. 2909-2975.

Tuncay, A. C. ve Ekmekçi, Ö. (2019). Sosyal Güvenlik Hukuku Dersleri. İstanbul: Beta Yayıncılik.

Yılmaz, S. (2010). Türk Borçlar Kanunu Tasarısında Sebep Sorumluluklarına İlişkin Hükümler. Ankara Üniversitesi Hukuk Fakültesi Dergisi. 59(3). 551-578.
Zevkliler, A. ve Gökyayla, E. (2019). Borçlar Hukuku Özel Borç İlişkileri. Ankara: Turhan Kitabevi. 